\title{
INTERNATIONAL LAW \\ -BETWEEN DIVISION (FRAGMENTATION) AND UNITY (CONSTITUTIONALISATION). LAW OF DIVISIONS OR LAW BEYOND BOUNDARIES?
}

\author{
Ewelina Cała-Wacinkiewicz*
}

\begin{abstract}
International public law is a legal system the scope of application of which is not determined by state borders. It is therefore a matter of fact that it is general in nature, which affects the fact that it is not conditioned by the legislation of individual states. In this perspective, one can say that, this law is a law "beyond boundaries" within the meaning of national borders. This approach shows that, international law goes beyond the boundaries of application of national law. This fact showing the absence of boundaries in the universal binding force of international law, however, does not preclude the existence of some divisions within it. They are related to the process of fragmentation which results in the separation of certain subsystems from this law. By this a division of international law into these subsystems, also called regimes is done. This, in turn, requires posing the question of whether the process of fragmentation threatens the unity of the international legal order. And whether the reverse process, referred to as constitutionalisation of this law, may be a specific remedy for this, which at the present stage of development of the international community is rather a certain postulate. An attempt to answer the above questions was adopted as the main purpose of this study, which will seek to resolve the essential question of whether international law is a law of divisions or a law beyond boundaries?
\end{abstract}

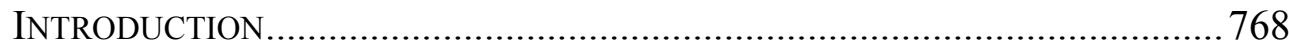

I. DIVISION (FRAGMENTATION) OF INTERNATIONAL LAW .........................771

II. UNITY (CONSTITUTIONALISATION) OF INTERNATIONAL LAW ................ 774

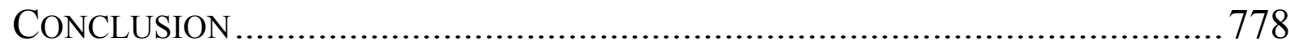

\section{INTRODUCTION}

The proposed title of the publication, "Law beyond boundaries", induces by its subject matter scope looking at law in a broad aspect of its validity, which — as can be assumed—should be "detached" from different

\footnotetext{
* Dr., Department of International Law, Faculty of Law and Administration of the University of Szczecin, Poland. Author of several dozens of papers on International Law, Human Rights and European Union Law. Member of the International Law Association; member of the Scientific Council of the Annals Reality of Politics, Estimates, Comments, Forecasts; member of Team Europe. Translated by Agnieszka Kotula, Ewelina Cała-Wacinkiewicz.
} 
legislations of individual states ${ }^{1}$. And although "the awareness that law applies to a particular territory was formed a long time ago" ${ }^{2}$ and is dominated by thinking about law through the prism of national borders ${ }^{3}$, it is safe to say that, national law is not the only legal system functioning in the normative sphere.

Today, this sphere-apart from the international dimension signaled above, being realized within the borders of individual states - also has an external dimension, the emanation of which is public international law. Constituting a particular superstructure over individual states, it arises as a result of their law-making activity. Therefore, it does not cause controversy that in the simplest terms, it is a legal system governing relations between the actors of this law. Taking into account the so-called "plural legislators" " concept, it cannot stay unnoticed that, states share the competence of an international legislator with international organizations, having no legislative monopoly in this regard.

In light of the foregoing, juxtaposing the international-law legal order with the title of the publication, one can indicate beyond doubt that, the scope of application of public international law is not determined by state borders. In this perspective, it is a law "beyond boundaries" and, therefore, such that not having a solely territorial (state) scope of application specific

\footnotetext{
${ }^{1}$ The presented text was published in the conference proceedings of the Second International Conference on Interdisciplinary Legal Studies 2015-Law Beyond Boundaries, Toronto, Canada, 2015.

${ }^{2}$ J. NOWACKI \& Z. TOBOR, WSTĘP Do PraWOZNAWSTwA 161 (Kraków: 2000). The authors indicate that, the term "territory" is of Roman origin. Territorium in Rome was a geographical sphere in which public authority was exercised. Ibidem, at 161 .

${ }^{3}$ A precise definition of the term "national border" was expressed on the basis of Polish doctrine of the subject by W. Staszewski. In this perspective, national borders define an area over which its territorial sovereignty extends and are usually defined as surfaces perpendicular to the surface of the earth, separating the territory of one state from the territory of other states or from areas not subject to territorial sovereignty (e.g., the high seas). National borders also divide the underground and the airspace. See: W. Staszewski, Granice Państwa, [in:] LeKsykon Prawa Międzynarodowego Publicznego 73 (A. Przyborowska-Klimczak \& D. Pyć eds., Warszawa 2012). A slightly different approach can also be found in T. Jasudowicz, according to whom the term "national border" is understood as a line on the earth's surface within which the territory of a state is contained and which separates it from the territory of another neighboring state or from an area not subject to the sovereignty of any state, namely the high seas. See: T. Jasudowicz, Granica Państwa, Prawo Międzynarodowe Publiczne, IV [in:] WielKa EnCYKLOPEdia Prawa 109 (J. Symonides \& D. Pyć eds., Warszawa 2014). On the subject of borders, see more in: V. Prescott \& G. D. Triggs, International Frontiers and Boundaries: Law, Politics and Geography (LeidenBoston 2008).

${ }^{4}$ S. Miko, Norm Conflict, Fragmentation, and the European Court of Human Rights, 54 Boston College Law Review 1362 (2013).
} 
to national law, has, in principle, a general ${ }^{5}$, universal character. It manifests itself not only in the fact that norms of public international law bind (by establishing a rule) all countries forming the international community, but also in the fact that, they bind the international community as a whole. General international law can be defined-invoking the words of R. Kwiecien - "as the law of and for the entire international community" 6 . While the "spatial sphere of application of domestic law is, in principle, the territory of a given state, including its sea-going vessels and aircraft, international law operates in a space defined as a community, and sometimes international community"7.

The above considerations presenting the status of public international law as a law beyond boundaries and a system at the same time do not, however, preclude the existence of some divisions within it. They are related to the process of fragmentation which results in the separation of certain subsystems from this law. By this, division of international law into said subsystems, also known as sections or regimes (which will, for instance, include international environmental law or international law of human rights, etc.) is done. This, in turn, requires posing the question ${ }^{8}$ of whether the process of fragmentation threatens the unity of the international legal order. And whether the reverse process, referred to as constitutionalisation of this law, may be a specific remedy for this, which at the present stage of development of the international community is rather a certain postulate.

An attempt to answer the above questions was adopted as the main purpose of this study, which will seek to resolve the essential-from the point of view of analyses carried out - question of whether international law is a law of divisions or a law beyond boundaries?

\footnotetext{
${ }^{5}$ In the context of international law the concept of universal law "can only be employed" in determining this part of international law which is potentially applicable across the international community. See: R. Kwiecień, Teoria i filozofia prawa międzynarodowego Problemy WyBRANE 81 (Warszawa: 2011). Whereas, a contrario, the term "regional law" will be identified with that part of international law which will potentially be applied in a particular area. Due to the nature of this study, the latter will remain outside the sphere of the discussion.

${ }^{6}$ R. Kwiecień, op. cit., at 82.

${ }^{7}$ J. Barcik \& Rozdział I. Zagadnienia ogólne. [in:] J. BARCiK \& T. Srogosz, Prawo MięDZYNAROdOWE PUBLICZNe 3 (2nd ed. Warszawa 2014)

${ }^{8}$ This question was previously asked by, inter alia: M. Koskenniemi, International Law: Between Fragmentation and Constitutionalism. Available at http://www.helsinki.fi/eci/Publications/Koskenniemi/MCanberra-06c.pdf. R. Deplano, Fragmentation and Constitutionalisation of International Law: A Theoretical Inquiry Source, 6(1) EUROPEAN Journal of Legal Studies (2013). H. G. Cohen, From Fragmentation to Constitutionalization, 25 (1) Pacific McGeorge Global Business \& Development LaW Journal (2012).
} 


\section{DIVISION (FRAGMENTATION) OF INTERNATIONAL LAW}

Research on the fragmentation of international law ${ }^{9}$ - so as to fully reflect its essence - entitles to understanding it as a process which produces (and under the influence of which are developed) individual sections of international law. These are derived from general international law, according to the criterion of the subject of a regulation, thereby focusing on a specific topic. In practice, "the use of the criterion of the subject of a regulation means that, groups of normative acts and groups of customary law norms are singled out according to the regulated circle of social relations" ${ }^{\prime \prime}$. This perception of the process of fragmentation constitutes a dynamic approach to this issue. Fragmentation within it is a process that lasts and certainly will continue to do so, inscribing itself in the development of the international legal order.

The dynamic approach in question can be distinguished, a contrario, from a static approach. In it, fragmentation will be identified with the state (factual and legal) of often a transient nature, which was created as a result of the development of international law. Thus, the already progressive fragmentation of this law has contributed to it. Its assessment will be made each time at a particular stage of this development.

This indicates that, as a result of the process of fragmentation of international law, recognized globally as a system of law, certain subsystems are being singled out, to which the doctrine assigns different names (from "specialist systems"11, to "functionally defined issue-areas"12, to sub-systems ${ }^{13}$ and meta-systems ${ }^{14}$, to, finally, regimes ${ }^{15}$ ).

Therefore, as noted by J. Menkes, the natural cause and foundation of

\footnotetext{
${ }^{9}$ It needs to be noted, though, that, this issue is backed by extensive subject literature. By way of an example, it is worth mentioning even the following publications: G. Hafner, Pros and Cons Ensuing from Fragmentation of International Law, 25(4) Michigan Journal of InTERNATIONAL LAW (2004). M. Koskenniemi \& L. Päivi, Fragmentation of International Law? Postmodern Anxieties, 15(3) LEIDEN Journal of InTERnATIONAL LaW (2002). G. Abi-Saab, Fragmentation or Unification: Some Concluding Remarks, 31(4) NYU JouRnal OF InTERNATIONAL LAW AND POLITICs (1999).

${ }^{10}$ St. Ehrlich, WstęP do NAUKi o PAŃstwie I Prawie 133 (Warszawa 1970).

${ }^{11}$ This term is employed by D. H. Joyner \& M. Roscini, A Contribution to Fragmentation Theory in International Law, [in:] NON-PROLIFERATION LAW AS A SPeCial Regime 1 (D. H. Joyner \& M. Roscini eds., Cambridge 2012).

${ }^{12}$ J. Pauwelyn, Fragmentation of International Law, Max Planck Encyclopedia of Public International Law 1. Available at http://www.mpepil.com.

${ }^{13}$ I. van Damme, Systemic Integration of International Law: Views from the ILC, the WTO CTE, and UNESCO, [in:] FRAGMENTATION: DIVERSIFICATION AND EXPANSION OF INTERNATIONAL LAW 61 (Ottawa-Ontario 2006). Proceedings of the 34th Annual Conference of the Canadian Council on International Law, Ottawa, October 26-28, 2005.

${ }^{14}$ J. Menkes, Jedność Nauki versus Wielość Nauk, 1 PrZegląd Strategiczny 57 (2012).

${ }^{15}$ J. Pauwelyn, op. cit., at 1.
} 
fragmentation is the discussed division into quasi-branches within the international law itself ${ }^{16}$. This accurate observation, expressed by the cited author, allows the perception of fragmentation of international law through its internal division happening as part of this normative order. This result in such sections, possible to be singled out today, as: international human rights law, international environmental law, international criminal law, international economic law, international investment law, international labor law, or even international sports law. The status of these sections is variedranging from those that have a well-established normative base, to those which are in statu nascendii. Their catalogue is not exhaustive, of course. Nor does it constitute depreciation of the classic "core" of international law in the form of international law of treaties, international humanitarian law, or international diplomatic and consular law. However, the development of contemporary international relations and in a way the need for specialized law results in the expansion of the material scope of international law, which is impossible not to notice.

For the sake of complementing and certain correctness of the argument, one needs to further note that the proposed way of understanding the concept of "fragmentation of international law" is not the only one on doctrinal grounds. The subject literature devoted to this subject, and, which is to some extent a derivative of reports of the International Law Commission $^{17}$, shows the diversity of the content. It is the result of not only

\footnotetext{
${ }^{16}$ J. Menkes, op. cit., at 56.

${ }^{17}$ One can name here: Report of the International Law Commission on the work of its fifty-second session, A/55/10, 1 May-9 June and 10 July-18 August, 2000, official records of the general assembly, fifty-fifth session, supplement No.10 - annex No 5: G. Hafner, Risks Ensuing from Fragmentation of International Law, II(2) Yearbook of the International Law Commission (2000); Report of the Study Group on fragmentation of international law, general assembly A/CN.4/L.628, 1 August, 2002, International Law Commission fifty-fourth session, Geneva, 29 April-7 June and 22 July-16 August, 2002; Report of the Study Group on fragmentation of international law: difficulties arising from the diversification and expansion of international law, general assembly A/CN.4/L.644, 18 July, 2003, International Law Commission fifty-fifth session, Geneva, 5 May-6 June, 2003 and 7 July-8 August, 2003; Report of the Study Group on fragmentation of international law: difficulties arising from the diversification and expansion of international law, general assembly A/CN.4/L.663/Rev.1 28 July, 2004, International Law Commission fifty-sixth session, Geneva, 3 May-4 June, 2004 and 5 July-6 August, 2004; Report of the Study Group on fragmentation of international law: difficulties arising from the diversification and expansion of international law, general assembly A/CN.4/L.676, 29 July, 2005, International Law Commission fifty-seven session, Geneva, 2 May-3 June and 11 July-5 August, 2005; Report of the Study Group of the International Law Commission, fragmentation of international law: difficulties arising from the diversification and expansion of international law, general assembly A/CN.4/L.682, 13 April, 2006, International Law Commission fifty-eighth session, Geneva, 1 May-9 June and 3 July-11 August, 2006, finalized by M. Koskenniemi, Conclusions of the Work of the Study Group on the Fragmentation of International Law: Difficulties Arising from the Diversification and Expansion of International Law, II(2) general assembly A/61/10, International Law Commission, fifty-eighth session, Geneva, 1 May-9 June and 3 July-11 August, 2006, YeARBoOK OF THE INTERNATIONAL LAW COMMISSION 251 (2006).
} 
a different approach to the topic, but above all the different understanding of the notion of "fragmentation of international law", which affects the way this phenomenon is interpreted.

Even a brief analysis of the position of the doctrine shows that, the discussed conceptual category is not presented uniformly. In addition to the above, it is also reduced to the specialization of international law ${ }^{18}$, (or functional specialization ${ }^{19}$ ), diversification of international-law legal order ${ }^{20}$ (or, simply, its diversity ${ }^{21}$ ), as well as a conflict of legal norms ${ }^{22}$.

However, explicit opting for the understanding the concept of "fragmentation" as a division on-going in the international law (which is the closest to the author of this study), allows leaving the cited categories outside the scope of this discussion. It seems all the more reasonable that often - establishing a conceptual relationship between them and the concept of "fragmentation"- the effect is taken as the cause and no notice of feedback between these concepts results in them being defined erroneously. For example, is it legitimate to identify fragmentation with the diversification of international law? Is it not the case perhaps that fragmentation - understood as a division-contributes to greater diversification of international law and this differentiation is also one of the reasons (causes) of fragmentation? Responding positively to a question posed in this way will rule out the possibility of semantic equation of both concepts.

In the context of the on-going process of fragmentation of international

\footnotetext{
${ }^{18}$ For example: I. Brownlie, Problems Concerning the Unity of International Law, I LE DRoIT

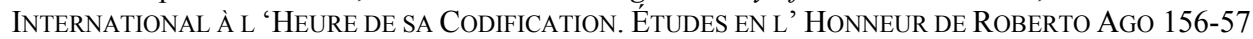
(1987).

${ }^{19}$ See: D. Pulkowski, Narratives of Fragmentation International Law between Unity and Multiplicity, EUROPEAN SOCIETY OF INTERNATIONAL LAW 1 (2005). Available at http://www.esilsedi.eu/sites/default/files/Pulkowski_ 0.PDF.

${ }^{20}$ This term features in: Fragmentation: Diversification and Expansion of International Law (Ottawa, Ontario 2006). Proceedings of the 34th Annual Conference of the Canadian Council on International Law, Ottawa, October 26-28, 2005.

${ }^{21}$ See: M. Craven, Unity, Diversity and the Fragmentation of International Law, 14(6) FINNISH YEARBOOK OF INTERNATIONAL LAW (2003). Moreover, on the subject of various aspects of diversification, see more in: A. H. Philipp, Through the Prism of Diversity-The Articles on State Responsibility in the Light of the ILC Fragmentation Report, 49 GERMAN YEARBOOK OF INTERNATIONAL LAW (2006). J. MONAR, ENLARGEMENT-Related Diversity IN EU JusticE AND Home Affairs: Challenges, Dimensions and Management Instruments (The Hague, December 2000). M. Prost \& C. P. Kingsley, Unity, Diversity and the Fragmentation of International Law: How Much Does the Multiplication of International Organizations Really Matter?, 5(2) CHINESE JOURNAL OF INTERNATIONAL LAW (2006). H. G. Schermers \& N. M. Blokker, International Institutional Law: Unity within Diversity, Unity and Diversity in Europe (3th revised ed., The Hague-London-Boston 2001). An Argument for Less Harmonisation and Centralisation (Frankfurter Institut 1992).

22 J. Pauwelyn, Conflict of Norms in Public International Law, How WTO Law Relates to Other Rules of International Law 9 (Cambridge 2003).
} 
law, it is impossible not to look at international law as a whole. Will the development of this process not threaten the unity of the international legal order? In order to be able to resolve this issue, it seems necessary to look at international law through the prism of constitutionalisation there of.

\section{UNITY (CONSTITUTIONALISATION) OF INTERNATIONAL LAW}

Fragmentation of international law, like its division, is often contrasted with its constitutionalisation ${ }^{23}$, serving to ensure the unity of internationallaw order, arousing probably no less controversy (than the former). They primarily involve the fact that the idea (concept) of international constitutionalism is closely related with the term "constitution" ${ }^{24}$. The latter, in turn, being associated more often with the constitutional law of individual states (rather than international law), as a rule, remains restricted to acts of fundamental importance for states.

This does not mean, however, that international law does not use this term. The various international organizations functioning under statute attribute it the nature of their constitution. They do this by default, intuitively, referring this term to the instrument of incorporation, or sometimes explicitly, as exemplified by the Constitution of the International Labour Organization $^{25}$.

\footnotetext{
${ }^{23}$ This issue has abundant subject literature. See for example: J. Klabbers, A. Peters \& G. Ulfstein, The Constitutionalization OF InTERnATIONAL LAW (Oxford 2009). S. C. Breau, The Constitutionalization of the International Legal Order, 21(2) LEIDEN JOURNAL OF INTERNATIONAL LAw (2008). L. Hancher, Constitutionalism, the Community Court and International Law, 25 Netherlands YearbooK of InTERnational Law (1994). M. Koskenniemi, Constitutionalism as Mindset: Reflections on Kantian Themes about International Law and Globalization, 8(1) Theoretical Inquiries in LAw (2007). S. Gill \& A. C. Cutler, New Constitutionalism and World Order: General Introduction, [in:] NEW CONSTITUTIONALISM AND WORLD ORDER (St. Gill \& A. C. Cutler eds., Cambridge 2014). S. Gill, Market Civilization, New Constitutionalism and World Order, [in:] New Constitutionalism And World Order (St. Gill \& A. C. Cutler eds., Cambridge 2014). A. C. Cutler, New Constitutionalism and the Commodity Form of Global Capitalism, [in:] NEW Constitutionalism and World Order (St. Gill, \& A. C. Cutler eds., Cambridge 2014). Ch. May, The Rule of Law as the Grundnorm of the New Constitutionalism, [in:] New Constitutionalism and World Order (St. Gill, A. C. Cutler eds., Cambridge 2014).

${ }^{24}$ The term "constitution" is derived from the Latin word constituere meaning in the verb form "to arrange", "to order". Constitution involves the system of government, the form of the state; it determines how to organize political and social life. It can be defined as an act of the highest legal force regulating fundamental institutions of the political and socio-economic system. The following meanings of the concept of constitution can be distinguished: (a) in the material (actual) sense as a real state system, regardless of whether it is recorded in the act of the highest legal force or not; (b) in the formal (legal) sense as standards resulting from a legal act with a special name. See: R. Krawczyk, Konstytucja i pozostałe Źródta Prawa Konstytucyjnego, [in:] Polskie Prawo Konstytucyjne (D. Górecki ed., Warszawa 2007). See also: A. Jamróz, Konstytucja jako najwyższy akt prawny. Kilka refleksji, [in:] W KręGU ZaGadnień KonstytuCyjnych (M. Kudej ed., Katowice 1999).

${ }^{25} 43$ JOURNAL OF LAWS OF 1948, item, at 308.
} 
Naturally, on the basis of academic debates, there is no shortage of arguments for assigning a constitutional status of the international community to the United Nations Charter of June 26, $1945^{26}$ (hereinafter referred to as the UN Charter), and although due to its ubiquitous nature and the rule expressed by the provisions of art. 103 of the UN Charter it is not devoid of legitimacy, one can find in the doctrine dissenting views indicating that, the Charter is not a constitutional source of the original entire international law in accordance with the ideal of the constitution as the Grundnorm of a legal system, nor is the entire international law subject to law-making control of the United Nations ${ }^{27}$. Especially the last argument is quite essential.

In the face of discrepancies regarding the status of the Charter, it seems reasonable to continue to explore the meaning of "constitutionalisation". It was pointed out by J. Zajadło who argued that, the discussions accompanying it are not so much about "constitution in a formal meaning", but rather about a complex of phenomena evidencing certain constitutional processes in the international community ${ }^{28}$. This is highlighted by the rather obvious distinction between such a reception of constitution (as an act of fundamental importance for the entire international community) and constitutionalisation understood as a phenomenon that allows for greater "conflictual unity" ${ }^{29}$ of international law. Thus, according to R. Deplano, the idea of constitutionalism is (...) an autonomous concept of international $\mathrm{law}^{30}$, which allows for detachment of the discussed conceptual category from constitutional law and "inscribing" in contemporary international law.

Against the background of the above the first aspect of the issue in question emerges, in which constitutionalisation is a certain process, placed in general international law. At the current stage of its development, "it is necessary to base this law on a more formalized basis ${ }^{31} "$. Therefore, constitutionalisation will mean-as noted by W. Czapliński-“"the development of certain standards of an ordering character, defining the

\footnotetext{
${ }^{26} 23$ JOURNAL OF LAWS OF 1947, item, at 90. This approach was favored by, for example: B. FASSBENDER, THE UnITED NATIONS CHARTER AS THE CONSTITUTION OF THE INTERNATIONAL COMMUNITY (Leiden-Boston 2009).

${ }^{27}$ M.W. Doyle, The UN Charter - A Global Constitution? [in:] RULING THE WORLD? CONSTitutionalism, InTERnAtional LaW and Global Governance 113 (J. L. Dunoff \& J. P. Trachtman eds., New York 2009).

${ }^{28}$ J. Zajadło, Konstytucjonalizacja prawa międzynarodowego, 3 PAŃstwo I Prawo 12 (2011).

${ }^{29}$ The term adopted after: I. de la Rasilla del Moral, The Unsolved Riddle of International Constitutionalism, 12 InTERNATIONAL COMMUNiTy LAW REview 110 (2010).

${ }^{30} \mathrm{R}$. Deplano, op. cit., at 69.

${ }^{31}$ W. Czapliński, Zasady ogólne prawa międzynarodowego, [in:] IV WIELKA ENCYKLOPEDIA PRAWA. Prawo Międzynarodowe Publiczne 597 (J. Symonides \& D. Pyć eds., Warszawa 2014).
} 
relationship between its individual elements and the power structure (including legislative powers). The unity of the system would be based on a hierarchy of norms with the leading significance of the UN Charter"32.

The importance of this observation does not need to be emphasized. Speaking of progressive fragmentation of international law which results in the creation (singing out) of new sections of this law, particular attention must be directed to defining (determining) rules on the relationship between international law and its individual parts, or in other words, between the general law and the specialist law (if we assume by simplification that, this character is borne by sections of international law generated as a result of fragmentation).

Thus, understood constitutionalisation rejects the need for the adoption of constitution in the formal sense. Going further, it also rejects, the use of constitutional concepts as a means for interpreting international law in general, and restoring coherence and unity within international law in particular" 33 . It does not, however, exempt from the need to develop rules to ensure the functioning of the various parts in a whole, so as to eliminate the potential for conflict situations. Of course, this must be done within the framework of international law understood systemically-so as to defend the thesis that it is one, though not uniform, legal order.

This observation corresponds to the second aspect of the analyzed issue, in which the process of constitutionalisation is positioned in the various sections of international law, not in the law as a whole. This in turn makes it necessary to refer to two important issues.

Firstly, despite the fact that at the level of general international law, the legitimacy of analyzing the concept of "constitutionalisation" through the prism of constitution in the formal sense was rejected, this kind of constitution, in a certain simplification, can be found in the sections of international law that have arisen in connection with the legislative activity of international organizations. In order to describe this state of affairs, one can invoke the doctrinal term of "mini-constitutionalisation of individual legal regimes," 34 where adopted statutes under which international organizations operate are assumed to be constitutions. The statutes are "generally semi-autonomous structures within the broader international

\footnotetext{
${ }^{32}$ Ibidem, at 597.

${ }^{33}$ R. Deplano, op. cit., at 68.

${ }^{34}$ The term adopted after: T. Widłak, O Konstytucjonalizacji prawa międzynarodowego-ku konstytucji społeczności międzynarodowej? VIII PROBLEMY WsPÓŁCZESNEGO PRAWA Międzynarodowego, EuropejSKiego i PorównAwCZego 68 (A. D. MMX ed.).
} 
legal order" ${ }^{35}$, and examples are provided even by the already invoked Constitution of the International Labour Organization and thus the section: international labor law ${ }^{36}$, which is the result of law-making activity of this organization.

Secondly, however, referring to the above where, after W. Czapliński, it was concluded appropriate to consider the notion of "constitutionalisation" as a process the aim of which is to "shape certain standards of a system - ordering nature" 37 , if we were to transpose it onto the ground of various sections of this law, we could paraphrase that, the purpose of the constitutionalisation occurring in them is to shape certain standards of a nature ordering a specific sub-system (section of international law). This "ordering" should also (and perhaps primarily) be referred to the relationship between those sections and general international law. Each contains its own legal norms, rules, and sometimes a catalogue of sources and a system of authorities (including judicial authorities).

Stopping at this observation it can be seen that, in this approachwhich is particularly interesting - the constitutionalisation process couples with the process of fragmentation of international law. This is despite the fact that originally these concepts were treated as opposing each other. Since looking for a way to determine the relationship, not just between the whole and its parts, but also between those parts, in line with the assumptions of the category of constitutionalisation, we attempt to introduce rules that shape the system ${ }^{38}$. This forces the progressive process of fragmentation of the international-law order on the international community.

This makes it legitimate to talk about the so-called "fragmented constitutionalisation", which was pointed to by R. Kwiecień. In his opinion, this fragmentation means the process of constitutionalisation covering only certain areas of international legal relations, e.g. trade relations, marine relations, or humanitarian issues. Thus, it would only be divisionary constitutionalisation, associated with the intensive development of special regimes in international law (the so-called self-contained regimes). Constitutionalisation within these regimes results in-according to the

\footnotetext{
${ }^{35}$ According to the author, one of the most prominent international organizations, and at the same time regimes of international law, that are undergoing constitutionalisation is the World Trade Organization (WTO). Ibidem, at 69.

${ }^{36}$ On the subject of this division see more in: L. FloreK \& M. SEWERYŃSKI, MięDZYNARODOWE Prawo PraCY (Warszawa 1988). A. Świątkowski, Międzynarodowe publiczne prawo pracyStandardy międzynarodowe, I(2-3) MięDZYNARODOwE PRAwo PRACY (Warszawa 2008).

${ }^{37}$ W. Czapliński, op. cit., at 597.

${ }^{38}$ The notion was suggested to me by professor St. Czepita (University of Szczecin) in the course of discussion on this subject, for which I would like to express particular gratitude to the Professor.
} 
referenced author-fragmentation of international law and may undermine the existence of the constitution of general international law, and thus may pose a threat to its normative unity ${ }^{39}$.

This view is important for at least two reasons. Firstly, it juxtaposes constitutionalisation with the fragmentation of international law. Secondly, it indicates the relationship existing between them. As a result of the fragmentation of international law its division follows. Constitutionalisation, in turn, will be an attempt to organize what arises as a result of that division, i.e., individual sections of international law, both in relation to general international law and in the mutual relationships between them.

\section{CONCLUSION}

A summary of the carried out discussion could somewhat perversely begin by saying that, at the current stage of development of the international community, despite the fact that it is fragmentation that must be addressed, we quite unambiguously defend the thesis of the unity of the international legal order.

This order, as not determined by boundaries of individual states (as there is no Polish, French, or German public international law), is the law of the international community of a universal nature, in the system policies of which its normative unity is inscribed. In this perspective, it is certainly a law beyond boundaries.

Fragmentation of international law that is taking place within its framework requires posing the question of whether this unity is threatened. May the internal sections of international law lead to its disintegration? And, does this law, being a law of divisions, have a chance to survive in this shape?

Looking for opportunities to resolve this extremely difficult issue, the process of constitutionalisation was resorted to, originally contrasting it with the process of fragmentation of international law and seeking in it a technical way to offset the effects of the latter. An assumption was adopted that, since fragmentation constitutes division, ensuring unity can be accomplished through constitutionalisation of international law. In carrying out this discussion, the postulate of creating a constitution within the general international law was rejected straight off, considering it as difficult to be carried out in practice, or even impossible. It was, therefore, agreed that the issue here is not constitution in the formal sense.

Therefore, we see in the constitutionalisation of general international

\footnotetext{
${ }^{39}$ R. Kwiecień, op. cit., at 158.
} 
law-understood as a postulate for the adoption of rules for developing a system (not the constitution) - certain security for the international-law system not to break apart and for the international law to be a law beyond boundaries (even now, not only in terms of national borders but also the boundaries that are defined by individual sections of international law).

Therefore, constitutionalisation should not be contrasted with the fragmentation of international law. It should provide (create framework for) the possibility of development of this law. In this sense we can say that constitutionalism is (...) a methodological approach to fragmentation ${ }^{40}$.

If, however, we were to consider the opposing assumption and to conclude that various parts will begin to evolve from general international law by acquiring ever greater autonomy, this would result in the fact that next to international law there would be other systems stemming from sections of international law. This, in turn, would undermine its normative unity. The way to do this is to adopt in universal (general) international law the principles that order the system ${ }^{41}$ and therefore those that define the relationship between the general law and the special law.

If this is done through constitutionalisation it will be a remedy for fragmentation, and international law will be a law beyond boundaries (meaning: above divisions).

\footnotetext{
${ }^{40} \mathrm{R}$. Deplano, op. cit., at 69 . The author is trying to explore the idea of international constitutionalism as a methodological approach specifically devised for interpreting international law. It aims to show whether constitutionalism is able to address normative conflicts and, consequently, restore coherence within international law. Ibidem, at 77.

${ }^{41}$ The term after W. Czapliński, op. cit., at 597.
} 